\title{
PRAKTIK TABUNGAN MASYARAKAT PEDESAAN DALAM PERSPEKTIF FIKIH MUAMALAH
}

(Studi Fenomenologi Tabungan Masyarakat Kampung Ongan Jaya Distrik Yapsi Kabupaten Jayapura)

\author{
Ayuk Dian Rahmawati \\ IAIN Fattahul Muluk Papua, Indonesia \\ Email: ayuukdian52@gmail.com \\ Amirullah \\ IAIN Fattahul Muluk Papua, Indonesia \\ Email: jayapura.amir01@gmail.com \\ Fachrudin Fiqri Affandy \\ IAIN Fattahul Muluk Papua, Indonesia \\ Email: affandyjo@gmail.com
}

\begin{abstract}
This thesis aims to analyze Ngudi Tentrem's savings practices from the perspective of fiqh muamalah in 4th Neighborhood, 2nd Hamlet, Ongan Jaya Village, Yapsi District, Jayapura Regency. This research also discusses the management's efforts to resolve the bad credit problems experienced by Ngudi Tentrem's savings practice. This study is qualitative research using primary and secondary data. The data analysis technique used is the phenomenological paradigm approach. The results of this study indicate that Ngudi Tentrem's savings practices in Ongan Jaya Village are carried out under the pillars and conditions of al-wadi'ah yad adhdhamanah which involve the contract of two people who have faith, the existence of goods entrusted, and also ijab and qabul. The effort is restructuring which the management will provide interest relief and extension of time to creditors to save trouble to fulfill his obligations. The other way to resolve the bad credit problem is to settle with deliberation peacefully. The phenomenon of the survival of Ongan Jaya village savings is the culture of mutual aid which is still very thick in rural areas. Sense of solidarity and trust make this savings can be borne from its inception in 1997 until now, even though it does not have an official legal entity. The absence of collateral in these savings also adds to the value of its uniqueness, so, the people of Ongan Jaya village, especially, 4th Neighborhood, 2nd Hamlet prefer to choose Ngudi Tenrem savings practice.
\end{abstract}

Keywords: Savings Practices, Wadiah yad adh-Dhamanah, Bad Credit 


\begin{abstract}
ABSTRAK
Skripsi ini bertujuan untuk menganalisis praktik tabungan Ngudi Tentrem dalam perspektif fikih muamlah di RT 004 RW 002 Kampung Ongan Jaya Distrik Yapsi Kabupaten Jayapura. Penelitian ini juga membahas tentang upaya pengurus dalam menyelesaikan permasalahan kredit macet yang dialami tabungan Ngudi Tentrem ini. Penelitian ini menggunakan pendekatan kualitatif dengan paradigma fenomenologi. Riset kualititif jenis penelitian yang menghasilkan data-data deskriptif dan lebih menekankan makna dari pada generalisasi. Hasil penelitian ini menunjukan bahwa Praktik tabungan Ngdi Tentrem di Kampung Ongan Jaya yang dilakukan sudah sesuai dengan rukun dan syarat al-wadi' ah yad adh-dhamanah dimana akad dua orang yang berakad, adanya barang yang dititipkan dan juga ijab dan qabul. Selain itu upaya yang dilakukan oleh pengurus untuk penyelesaiakan permasalahan kredit macet pada tabungan ini pun telah sesuai dengan cara penyelesaian kredit macet oleh sebuah bank, yaitu dengan melakukan restructuring (penataan kembali) dimana pengurus akan memberikan keringanan bunga serta perpanjangan waktu kepada kreditur. Jika dengan cara ini juga tidak dapat mengatasi permasalahan tersebut maka kredit macet akan diselesaikan menggunakan penyelesaian kredit masalah secara damai. Fenomena tentang bertahannya tabungan masyarakat kampung Ongan Jaya adalah budaya gotongroyong yang masih sangat kental didaerah pedesaan. Rasa kesetiakawanan dan kepercayaan inilah yang membuat tabungan ini bisa betahan dari awal dibentuknya pada tahun 1997 hingga sekarang meskipun belum memiliki badan hukum yang resmi. Ketiadaan agunan pada tabungan ini, juga menambah nilai keunikan, sehingga masyarakat kampung Ongan Jaya khususnya RT 004 RW 002 lebih memilih tabungan Ngudi Tenrem ini dalam aktifitas menabungnya.
\end{abstract}

\title{
Kata Kunci : Praktik Tabungan, Wadi'ah yad adh-Dhamnah, Kredit Macet
}

\section{PENDAHULUAN}

Masyarakat di negara maju dan berkembang sangat membutuhkan bank sebagai tempat untuk melakukan transaksi keuangannya. Mereka menganggap bank sebagai lembaga keuangan yang aman dalam melakukan berbagai macam aktivitas keuangan. Aktivitas keuangan yang sering dilakukan masyarakat di negara maju dan negara berkembang antara lain aktivitas penyimpanan dan penyaluran dana. Di negara maju, bank menjadi lembaga yang strategis dan memiliki peran yang sangat penting dalam perkembangan perekonomian negara. Di negara berkembang, kebutuhan akan bank tidak hanya terbatas pada penyimpanan dan penyaluran dana saja, akan tetapi juga terhadap pelayanan jasa yang ditawarkan bank. (Ismail,2011:30) 
Secara ekonomi tabungan dapat diartikan mendorong terbinanya surplus konsumsi dalam bentuk simpanan. Hal tersebut sangat penting untuk terpenuhinya kebutuhan jangka panjang. Semakin meningkatnya kebutuhan masyarakat pada masa ini, masyarakat juga harus pintar untuk mengatur kebutuhan dan pengeluran setiap harinnya. Sedangkan dalam dunia perbankan syariah sendiri tabungan yaitu simpanan berdasarkan akad wadiah atau investasi dana berdasarkan akad mudharabah atau akad lain yang tidak bertentangan dengan prinsip syariah yang penarikannya hanya dapat dilakukan menurut syariat dan ketentuan tertentu yang disepakati. (Soemitra Andri,2017:71)

Seperti halnya praktik tabungan pada umumnya, yang memiliki tujuan untuk dapat mengatur keuangan dengan baik dan juga dapat merencanakan masa depan. Tabungan Ngudi Tentrem adalah salah satu kegiatan berbasis tabungan uang yang terdapat di Kampung Ongan Jaya khususnya di RT 004 RW 002 Distrik Yapsi Kabupaten Jayapura. Mengapa tabungan ini di namakan Tabungan Ngudi Tentrem? Ngudi Tentrem sendiri berasal dari bahasa Jawa yaitu Ngudi artinya mencari sedangkan tentrem artinya ketentraman. Dengan demikian, pendiridari tabungan Ngudi Tentrem bertujuan bahwa dengan keberadaan tabungan ini para anggota dapat mencari ketentraman hidup yang di inginkan.

Tabungan Ngudi Tentrem ini sudah berdiri sejak 22 tahun yang lalu tepatnya pada akhir tahun 1997. Namun pemberian nama Ngudi Tentrem pada tabungan baru diberikan pada awal tahun 1999 hingga saat ini. Walaupun telah berdiri sejak 22 tahun lalu, namun tabungan ini belum memiliki badan hukum dan badan pengawas. Selama terbentuknya tabungan ini masyarakat kampung Ongan Jaya hanya menggunakan prinsip sukarela dan kepercayaan bersama serta musyawarah mufakat dalam mengambil sebuah keputusan. Masyarakat kampung Ongan Jaya khususnya di RT 004 RW 002 dalam kegiatan ekonomi khususnya dalam aktifitas menabung lebih memilih menabung pada Tabungan Ngudi Tentrem. Alasan mereka menggunakan tabungan Ngudi Tentrem yaitu sudah saling mengenal satu sama lain antara pengurus dan anggota, yang membuat anggota merasa aman dan percaya bahwa dana yang mereka simpan akan dimanfaatkan sebaik-baiknya. Selain itu, pada tabungan Ngudi Tentrem ini juga dapat melakukan peminjaman dana dengan sistem yang mudah dan cepat serta tanpa menggunakan agunan. Ditambah lagi para anggota yang peminjaman dana akan pemperoleh jasa pinjaman yang diberikan diakhir pembagian tabungan Jasa pinjaman ini diperoleh dari potongan jasa sebesar 10\% setiap kali anggota memlakukan pinjaman. Kemudian dari $10 \%$ tersebutakan dibagikan kepada jasa si penabung sebesar $55 \%$, jasa si peminjam 29\%, insentif pengurus mendapat $15 \%$, danyang $1 \%$ dimasukkan kedalam adminitrasi tabungan. Beberapa faktor inilah 
yang menarik minat anggota untuk menggunakan tabungan Ngudi Tentrem dalam hal menabung dan meminjam uang (Muryadi, 2020).

Selama 22 tahun berjalan tak jarang tabungan Ngudi Tentrem ini sering dilanda beberapa masalah salah satunya yaitu kredit macet atau kredit bermasalah. Kredit macet adalah hal yang wajar terjadi pada sebuah simpan pinjam, dimana tak jarang anggota kesulitan untuk mengembalikan dana pinjaman tersebut. Biasanya hal ini terjadi karena, faktor bunga pinjaman yang cukup besar, waktu jatuh tempo yang cukup cepat dan beberapa alasan lainya yang dapat mengakibatkan kredit macet.

\section{KAJIAN LITERATUR}

\section{Pengertian Praktik}

Praktik dalam Kamus Besar Bahasa Indonesia adalah pelaksanaan secara nyata apa yang di sebutkan dalam teori (Setiawan Ebta, 2012). Praktik menurut Sujana 2005:157-158, yakni sebagai metode dalam pembelajaran yang digunakan dengan tujuan melatih serta meningkatkan kemampuan peserta didik dalam menerapkan pengetahuan dan keterampilan yang telah diperoleh untuk dilakukan di kehidupan nyata atau lapangan, pekerjaan, atau tugasyang sebenarnya.

Berdasarkan pengertian di atas, maka dapat disimpulkan bahwa praktik adalah suatu kegiatan di lapangan berdasarkan teori yang bertujuan agar seseorang atau kelompok dapat meningkatkan kemampuan dalam menerapkan pengertahuan dan keterampilan yang sudah dipelajari serta mengetahui langsung tentang prosedur kerja dan lebih mandiri.

\section{Pengertian Tabungan}

Tabungan adalah menyimpan uang dalam jumlah tertentu atau dalam kurun waktu yang sudah ditentukan, dan tentunya dengan memiliki satu tujuan atau goal (Widayanti Nuning, 2015:15). Pengertian tabungan menurut UndangUndang No.10 tahun 1998 tentang Perbankan adalah simpanan yang penarikannya hanya dapat dilakukan menurut syarat-syarat tertentu yang disepakati, tetapi tidak dapat ditarik dengan giro, billyed giro, atau alat lainya yang dipersamakan dengan itu. Tabungan sendiri memilki arti adalah bagian dari pendapatan yang tidak dikonsumsikan. Jadi disimpan dan akan digunakan di masa yang kan datang (Paulin kay Vera,2013:96). 


\section{Tabungan Ngudi Tentrem}

Tabungan Ngudi Tentrem adalah sebuah kelompok tabungan masyarakat yang terdapat di kampung Ongan Jaya. Mengapa dinamakan Tabungan Ngudi Tentrem? Jadi, kata "Ngudi Tentrem" berasal dari bahasa jawa yaitu Ngudi artinya mencari sedangkan Tentrem artinya ketentraman. Sehingga dapat diartikan bahwa Tabungan Ngudi Tentrem adalah tabungan yang mencari ketentraman. Tabungan ini berdiri sejak tahun 1999 hingga sekarang, dengan pelaku utamanya adalah ibu-ibu kampung Ongan Jaya tepatnya yang berada di RT 004 RW 002 yang mayoritas penduduknya adalah suku Jawa dan Sumatra.

Pada dasarnya tabungan Ngudi Tentrem ini sama dengan tabungan pada umumnya. Tabungan ini melakukan transaksi tabungan seperti di bank yaitu nasabah yang ingin menabungkan uangnya dapat langsung datang ke bank dengan membawa buku rekening. Di tabungan Ngudi Tentrem ini anggotanya juga disediakan buku anggota dimana setiap kali anggota akan menabung maka buku tersebut harus di bawa dan di setorkan kepada pengurus beserta sejumlah uang yang ingin di tabungkan.

Tak hanya menabung, pada tabuungan Ngudi Tentrem ini juga dapat melakukan pinjaman. Sehingga para anggota sangat terbantu dengan keberadaan tabungan ini. Selain dapat membantu memenuhi kebutuhan hidup sehari-hari keberadaan tabungan ini juga membuat anggota menjadi lebih mandiri contohnya anggota kini bisa membuka usaha sendiri dari hasil pinjaman pada tabungan Ngudi Tentrem ini sehingga anggota dapat memeperoleh penghasilan tambahan dari usahanya tersebut.

\section{Fikih Muamalah}

Fikih Muamalah terdiri dari dua kata, yaitu fiqih dan muamalat. Pengertian fiqih menurut bahasa berasal dari kata faqiha, yafqahu, fiqhan yang berarti mengerti, atau memahami (Wardi Muslich Ahmad, 2010:1).. Pengertian fiqh menurut istilah, sebagai mana dikemukakan oleh abdul Wahab Khallaf adalah sebagai berikut: "Fiqh adalah ilmu tetang hukumhukum syara' yang bersifat amaliah yang mengambil dari dalil-dalilyang terperinci, atau fiqh adalah himpunan hukum-hukum syara' yang bersifat amaliah yang diambil dari dalil-dalil yang terperinci”. Adapun lafal muamalat berasal dari kata amala, yumilu, muamalatan yang artinya: "Melakukan interaksi dengan orang lain dalam jual beli dan sesamanya". 
Merujuk pada definisi yang dikemukakan tersebut, maka dapat dipahami bahwa fikih muamalah adalah hukum-hukum syara' yang mengatur perbuatan manusia yang digali dari dalil-dalil al-Qur'an maupun hadits yang terperinci yang berhubungan dengan persoalan-persoalan dunia (ekonomi). Atau lebih singkatnya adalah hukum Islam tentang kegiatan ekonomi yang dilakukan oleh manusia. Seperti al-Bay' (jual beli), ijarah (sewa menyewa), qard (utang piutang), musyarakah dan mudharabah (kerja sama bisnis), rahn (gadai), wakalah (perwakilan, agen, atau distributor), hiwalah (pelimpahan tanggung jawab melunasi hutang), kafalah (penjaminan), al-Wadi'ah (titipan) dan lain-lain (Harun, 2017:3). Hukum mualamat memiliki 4 prinsip utama yaitu: Hukum asal segala betuk muamalat adalah mubah, muamalat dilakukan atas dasar suka rela, muamalat dilakukan atas dasar menarik manfaat dan menolak mudharat, dan muamalat dilakukan atas dasar menegakkan keadilan.

\section{Prinsip Wadi'ah}

Menurut hanafiyah, wadi'ah adalah memberikan kekuasaan kepada orang lain atas suatu barang yang dimiliki dengan tujuan untuk dijaga, baik secara verbal atas dengan isyarat (dilalah). Sedangkan menurut Syafiyah dan Malikiyah, wadi'ah adalah pemberian mandat untuk menjaga sebuah barang yang dimiliki atau barang secara khusus dimiliki seseorang dengan cara-cara tertentu (Sa'diyah Muhdayatus,2019: 13). Dalam bisnis modern wadi'ah berkaitan dengan penitipan modal pada perbankan baik berupa tabungan dan giro.

Landasan hukum wadi'ah terdapat pada surah An-Nisaa ayat 58 dan surah Al-Baqarah ayat 283. Sedangkan untuk rukun dan syarat wadi'ah yaitu adanya benda yang dititipkan, adanya shighat, adanya orang yang menitipkan dan juga adanya orang yang dititipkan. Menurut bentuknya wadi'ah terbagi menjadi dua yaitu wadi'ah yad al-Amanah yaitu bentuk penitipan murni dan wadi'ah yad adh-Dhamanah yaitu titipan yang boleh dimanfaatkan. Berikut adalah skema dari wadi'ah yad al-Amanah dan wadi'ah yad adh-Dhamanah. 
Gambar 1.1 Skema al- Wadi'ah yad al-Amanah

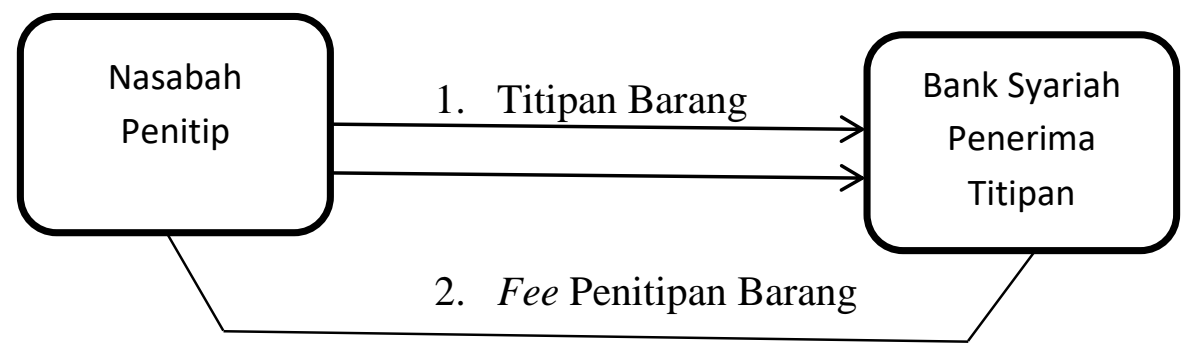

3. Pengembalian Barang Titipan

Sumber data: Fikih Muamalah II Teori dan Praktik 2019

\section{Gambar 1.2 Skema Al-Wadi'ah Yad Dhamanah}

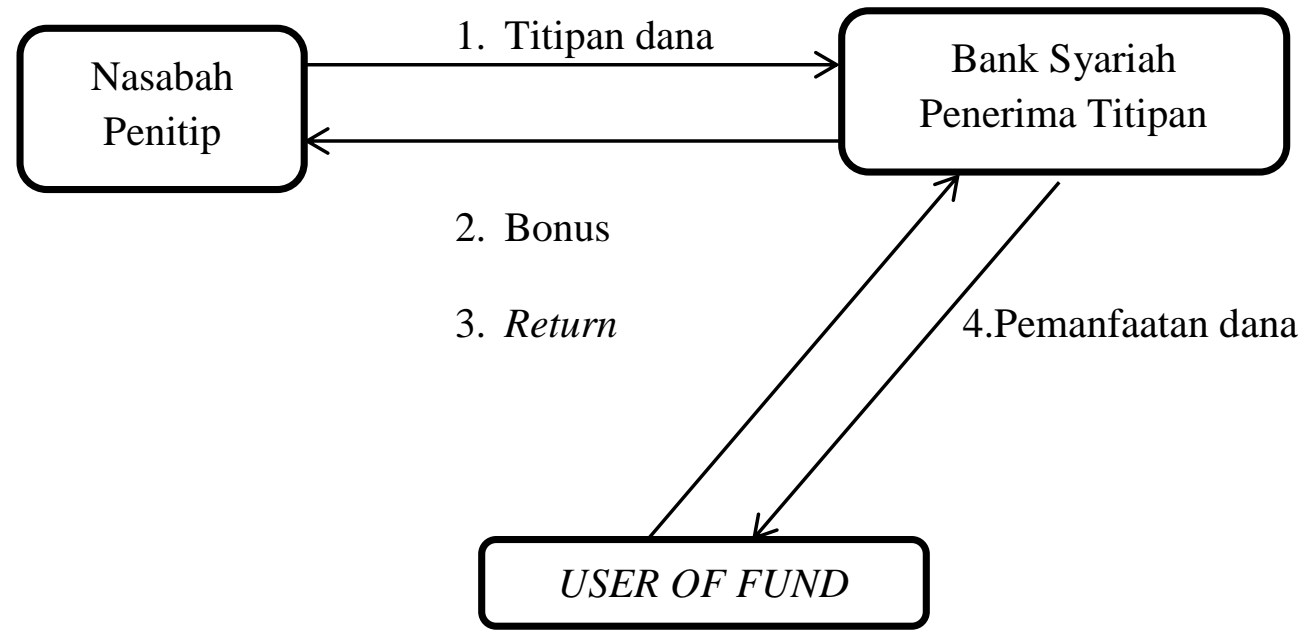

Sumber data: Fikih Muamalah II Teori dan Praktik 2019

\section{Prinsip Al-Qardh}

Secara etimologi, qardh berarti al-qath'u (potongan). Harta yang dibayarkan kepada muqtaridh (yang diajak akad qardh) dinamakan qardh, sebab merupakan potongan dari harta muqridh (orang yang membayar). Secara sederhana qardh atau pinjaman adalah akad pemberian pinjaman dari bank kepada nasabah yang dipergunakan untuk kebutuhan mendesak. Pengembalian pinjaman ditentukan dalam jumlah yang sama dan dalam jangka waktu tertentu (sesuai kesepakatan bersama) dan pembayarannya bisa secara angsuran atau sekaligus. Sumber dana qardh diperoleh dari dana 
wadi'ah atau dana khusus yang disediakan oleh bank atau lembaga keuangan lainnya (Ifham Ahmad, 2015: 183). Selain sebagai produk pelengkap kepada nasabah, manfaat lain yang dapat dari qardh adalah berupa manfaat nonfinansial yaitu kepercayaan dan loyalitas nasabah kepada bank tersebut. Risiko dalan qardh terhitung tinggi karena ia dianggap pembiayaan yang tidak ditutup dengan jaminan.

Landasan hukum al-Qardh terdapat pada surah al-Baqarah ayat 245 dan surah al-Hadid ayat 11 . Rukun dan syarat al-qardh adalah adanya peminjam, adanya pemberi pinjaman, adanya sejumlah dana dan adanya ijab qabul serta pelaksanaan peminjaman harus berdasarkan kerelaan kedua belah pihak yang melakukan akad dan dana yang digunakan bermanfaat dan halal.

\section{Tinjauan Umum Tentang Kredit}

Istilah kredit berasal dari bahasa latin "credere" yang berarti kepercayaan. Dapat dikatakan dalam hubungan ini bahwa kreditur atau pihak yang memberikan kredit (bank) dalam hubungan perkreditan dengan debitur (nasabah penerima kredit) mempunyai kepercayaan bahwa debitur dalam waktu dan dengan syarat-syarat yang telah disetujui bersama dapat mengembalikan kredit yang bersangakutan (Usman Rachmadi, 2003:236).

Menurut Usman: 2003 bahwa secara umum jenis-jenis kredit dapat ditinjau dari beberapa sudut antara lain:

a. Ditinjau dari sudut kegunaan

1) Kredit Konsumtif

2) Kredit Produktif

b. Ditinjau dari Sudut Jaminan

1) Kredit dengan jaminan

2) Kredit tanpa jaminan

c. Dintinjau dari Sektor Usaha

1) Kredit Pertanian

2) Kredit Peternakan

3) Kredit Industri

4) Kredit Pertambangan

5) Kredit Pendidikan

6) Kredit Profesi

7) Kredit Perumahan

d. Ditinjau dari Sudut Jangka Waktu

1) Kredit jangka pendek

2) Kredit jangka menengah 
3) Kredit jangka panjang

\section{Kredit Macet}

Menurut Rene Setyawan, mengemukakan bahwa kredit macet dapat disebabkan oleh berbagai factor, baik factor interbal maupun eksternal. Faktor internal peyebab timbulnya kredit macet yaitu penyimpangan dalam pelaksanaan prosedur perkreditan, itikad kurang baik dari pemilik, pengurus, atau pegawai bank, lemahnya system adminitrasi dan pengawasan kredit serta lemahnya system informasi kredit macet, sedangkan factor eksternal penyebab timbulnya kredit macet adalah kegagalan usaha debitur, musibah terhadap debitur, atau terhadap kegiatan usaha debitur, serta menurunnya kegiatan ekonomi dan tingginya suku bunga kredit (Setyawan Rene, 1994:7).

\section{Penyelamatan Kredit Bermasalah}

Penyelamatan kredit bermasalah adalah suatu langkah yang dilakukan ole suatu bank dalam mengelola kredit bermasalah yang masih memiliki prospek dalam pengelolaan usahanya sebagai upaya dalam meminimalisir kemungkinan terjadinya kerugian bagi suatu bank. Biasanya dalam proses penyelamatan kredit, account officer melihat dan menanalisis apakah debitur memiliki kredit bermasalah ini masih bisa diupayakan untuk diangkat status kredit macetnya menjadi kredit lancer, dengan langkah awal melihat dan mnegamati perkembangan usaha debitur apakah masih memungkinkan memiliki kemampuan untuk mengangsur ataukah sudah tidak menjalankan usahanya lagi. Apabila si debitur masih memiliki kemampuan mengangsur, namun tidak seluruh angsuran sesuai dengan persetujuan kredit di awal, maka pihak bank akan langsung melakukan langkah penyelamatan kredit dengan cara sebagai berikut:

a. Penjadwalan kembali (Rescheduling)

b. Persyaratan kembali (Reconditioning)

c. Penataan kembali (Restructturing)

\section{Penyelesaian Kredit Bermasalah}

Adalah suatu langkah bank dalam menyelesaikan kredit bermasalah melalui lembaga hukum. Yang dimaksud dengan lembaga hukum dalam hal ini adalah Panitia Urusan Piutang Negara (PUPN) dan Derektorat Jendral Piutang dan Lelang Negara (DJPLN), melalui badan peradilan, dan 
melalui Arbitrase atau Badan Alternatif Penyelesaian Sengketa (Andrianto, 2020: 190).

Apabila penyelesaian sebagaimana tersebut diatas tidak berhasil dilaksanakan, pada umumnya upaya yang dilakukan bank dilakukan melalui prosedur hukum. Sehubungan dengan hal tersebut,sesuai dengan peraturan perundang-undangan yang berlaku terdapat beberapa lembaga dan berbagai sarana hukum yang dapat digunakan untuk mempercepat permasalahan kredit macet perbankan.

Penyelesaian kredit bermasalah dilakukan melalui 2 (dua) cara yaitu sebagai berikut:

1. Penyelesaian Kredit Bermasalah Secara Damai

Penyelesaian kredit bermasalah secara damai dapat dilakukan terhadap debitur yang beritikad baik untuk menyelesaikan kewajibanya dan cara yang ditempuh dalam penyelesaian ini dianggap lebih baik dibandingkan alternative penyelesaian melalui saluran hukum.

Jenis-jenis dan ketentuan penyelesaian kredit secara damai meliputi:

a. Pemberian fasilitas keringanan Bunga, pemberian fasilitas keringana bunga hanya diberikan kepada penunggak dengan kolektibilitas diragukan,macet dan kredit yang telah dihapus bukukan.

b. Penjualan Agunan dibawah tangan, penjualan agunan di bawah tangan dilakukan agar debitur masih diberikan kesempatan untuk menawarkan / menjual sendiri agunannya.

2. Penyelesaian Kredit Bermasalah Melalui Saluran Hukum

Penyelesaian jenis ini dilakukan apabia upaya retrukturisasi/ penyelesaian secara damai sudah di upayakan secara maksimal dan belum memberikan hasil atau debitur tidak menunjukkan itikad baik dalam menyelesaikan kewajibanya, maka penyelesaian dapat ditempuh melalui saluran hukum yaitu Badan Urusan Piutang Lelang Negara (BUPLN) atau Panitia Urusan Piutang Negara (PUPN) atau pengadilan Negeri.

Sedangkan bank syariah memiliki beberapa cara dan tahapan yang dapat dilakukan untuk mengatasi bagi orang yang sewaktu-waktu gagal bayar atau yang disebut kredit macet, diantaranya yaitu, melakukan pengecekan terlebih dahulu kondisi pihak penghutang, peminjam atau nasabah dalam proses pemberian dana untuk kegiatan bisnis atau usaha (Hadi Muhammad, 2019:43). Sehingga kemungkinan terjadinya kredit macet sangatlah kecil. 


\section{METODE PENELITIAN}

Penelitian ini menggunakan pendekatan kualitatif dengan paradigma fenomenologi. Riset kualitatif jenis penelitian yang menghasilkan data-data deskriptif berupa kata-kata tertulis atau lisan dari orang-orang atau perilaku yang diamati serta hasil dari penelitian kualitatif lebih menekankan makna dari pada generalisasi (Sugiono, 2014:1). Pengambilan semple data dilakukan secara purposive dan snowbaal, dimana peneliti lebih menekankan pada pemahaman mengenai masalah-masalah dalam kehidupan social berdasarkan kondisi realitas atau natural setting yang holistic, kompleks dan rinci (Anggito Albi, 2018:9). Dimana sumber data diperoleh langsung dari narasumber yaitu pengrurus dan anggota tabungan di Kampung Ongan Jaya.

\section{Teknik Analisis}

Menurut Kuswanto: 2009 data diperoleh dari lapangan akan dilakukan analisis melalui tahap-tahap analisis data fenomenologi sebagai berikut:

1. Penelitian mendeskripsikan seleuruhnya fenomena yang dialami oleh informan peneliti. Seluruh hasil wawancara ditraskipsikan kedalam bahasa tulisan.

2. Peneliti menginventarisasikan pernyataan-pernyataan penting yang relevan dengan topik masalah. Pada tahap ini, peneliti harus bersabar untuk menunda penilaian (bracketing/epoche).

3. Peneliti mengklasifikasi pernyataan-pernyataan tadi kedalam tema-tema atau unit makna dan menyisihkan pernyataan yang tumpang tindih ataupun berulang-ulang. Pada tahap inilah, peneliti menuliskan deskrisi tentang apa yang dialami oleh informan (deskripsi structural).

4. Peneliti kemudian mengkontruksikan seluruhnya penjelasan-penjelasan tentang makna dan esensi pengalamannya.

5. Peneliti melaporkan hasil penelitiannya. Laporan tersebut yang menunjukkan adanya kesatuan makna berdasarkan pengalaman seluruh informan. Setelah semua itu dilakukan, peneliti menulis deskripsi gabungannya (compesite description).

Analisis data berlangsung secara bersama-sama dengan proses pengumpulan data dengan alur tahapan sebagai berikut: 
Gambar 3.1 Alur Analisis Data

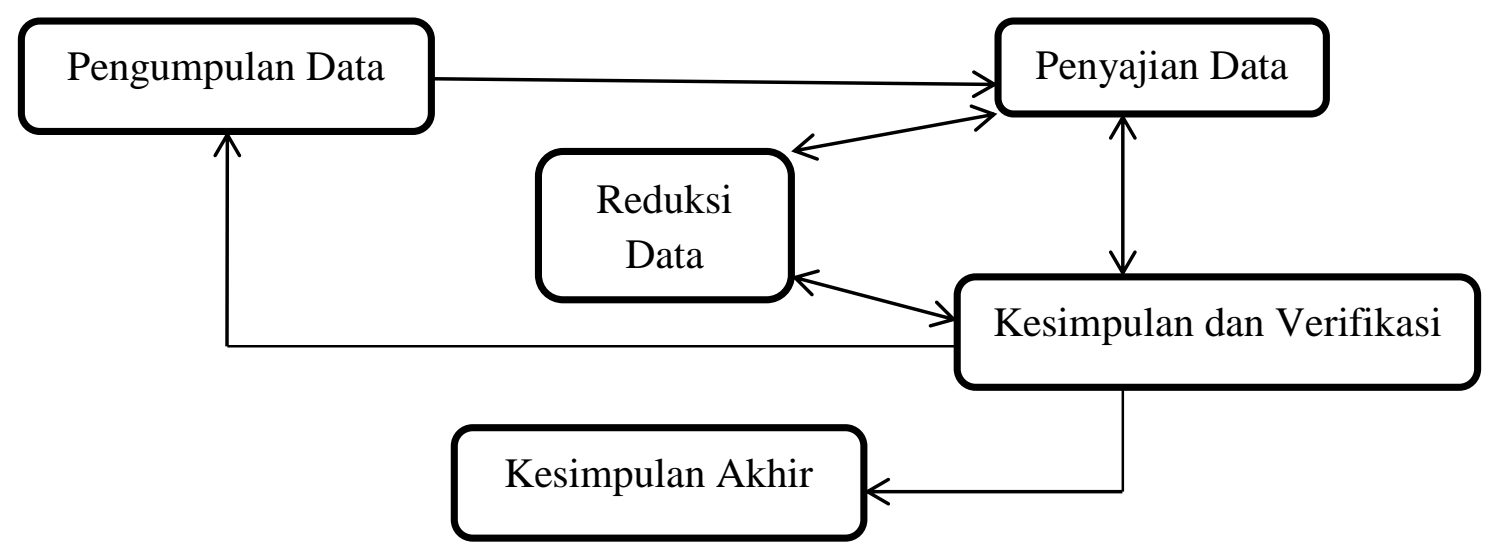

Sumber data: Metodologi Penelitian Bisnis \& Ekonomi, 2019

\section{HASIL DAN PEMBAHASAN}

Hasil dari penelitian tabuangan masyarakat ini adalah bahwa akad yang dilakukan pada tabungan ini telah sesuai dengan rukun dan syarat wadi'ah sebagaimana telahdipaparkan pada bab sebelumnya. Adapun kegiatan yang dilakukan dalam memenuhi akad wadi'ah dan juga untuk menyelesaikan permasalah kredit macet sebagai berikut:

1. Praktik tabungan masyarakat kampung Ongan Jaya dalam perspektiffikih muamalah.

a. Berdasarkan observasi yang dilakukan oleh peneliti, tekait dengan praktik tabungan masyarakat kampung Ongan Jaya calon anggota tabungan yang ingin menjadi anggota harus membayarkan simpanan pokok sebesar Rp. 1.100.000 kemudian pengurus akan memberikan buku anggota sebagai sebagai identitas bahwa telah resmi menjadi anggota.

b. Beberapa temuan dilapangan menunjukkan bahwa pada tabungan ini terdapat potongan jasa pinjam diawal sebesar $10 \%$ setiap meminjam. Dari pinjaman tersebut, pengurus akan membaginya menjadi 55\% sebagai jasa tabungan, 29\% sebagai jasa pinjaman, $15 \%$ sebagai intensif pengurus dan yang $1 \%$ sebagai administrasi. Namun tabungan ini belum memiliki badan hukum resmi dari awal di bentuknya hingga saat ini. 
c. Berdasarkan hasil temuan peneliti menganalisa, bahwa pelaksanaan tabungan ini telah sesuai dengan beberapa prinsip muamalah yaitu telah dilakukan atas dasar suka rela, dilakukan atas dasar menarik manfaat dan menolak mudharat, dan dilakukan dengan menegakkan keadilan.

d. Hasil temuan peneliti menunjukkan bahwa tabungan di kampung Ongan Jaya bernama “ Ngudi Tentrem” yang berasal dari bahasa jaya yaitu mencari ketentraman. Selain itu yang membuat tabungan ini bertahan dari awal dibentuk hingga saat ini yaitu budaya kegotongroyongan yang masih kental di daerah pedesaan serta rasa kesetiakawanan dan kepercayaan yang membuat anggota masih memilih tabungan ini dalam kegiatan menabungnya.

2. Upaya pengurus dalam menyelesaikan permasalahan kredit macet anggota tabungan di kampung Ongan Jaya.

Berdasarkan hasil observasi peneliti menghasilkan bahwa pada tabungan di kampung Ongan Jaya, pengurus akan melakukan tahapan penyelamatan kredit yang diharapkan dapat meminimalisir terjadinya kredit macet yaitu dengan cara restructtring (penataan kembali). Namun jika kredit tidak dapat diselamtakan maka langkah yang akan di ambil oleh pengrus tabungan dalam menyelesaikan permasalahan kredit macet yaitu dengan penyelesaian secara damai karena cara ini dianggap lebih baik di bandingkan melalui saluran hukum.

\section{Pembahasan}

1. Praktik tabungan masyarakat kampung Ongan Jaya dalam perspektif fikih muamalah

Dalam fikih muamalah terdapat dua akad yaitu wadi'ah dan qardh. Akad wadi'ah adalah suatu titipan yang dititipkan oleh suatu pihak (pemilik) kepada pihak lain dengan tujuan untuk dijaga. Menurut hanafiyah, wadi'ah adalah pemberian kekuasaan kepada orang lain atas suatu barang yang dimiliki dengan tujuan untuk dijaga, baik secara verbal atas dengan isyarat (dilalah). Sedangkan akad qadh adalah suatu akad antara dua pihak untuk dimanfaatkan dengan ketentuan bahwa uang atau barang tersebut harus dikembalikan persis seperti yang ia terima dari pihak pertama. Menurut Fatwa DSN No. 19/DSN-MUI/IV/2001, qardh adalah sebagai suatu akad pinjaman kepada nasabah dengan ketentuan 
bahwa nasabah wajib mengembalikan dana yang diterimanya pada waktu yang telah ditetapkan oleh kedua belah pihak.

Tabungan masyarakat yang ada di kampung Onga Jaya yaitu berlandaskan prisip akad wa'diah. Akan tetapi jika melihat praktik pinjaman pada tabungan ini maka hal tersebut sesuai dengan prinsip akad qardh dimana selain sebagai suatu produk pelengkap, akad ini juga memiliki manfaat nonfinansial yaitu kepercayaan dan loyalitas nasabah kepada bank. Ditambah lagi akad qardh ini pembiayaannya yang tidak ditutup dengan jaminan.

Sebagaimana dari hasil wawancara yang telah dilakukan peneliti dengan anggota tabungan mendapatkan hasil bahwa parktik tabungan masyarakat kampung Ongan Jaya adalah anggota menitipkan dananya kepada pengurus tabungan. Kemudian pihak pengurus akan menerima dan menjaga dana masyarakat tersebut. Atas dasar kesepakatan kedua belah pihak bahwa dana yang dititipkan tersebut dapat dimanfaatkan oleh pihak pengurus yang diharapkan dapat menghasilkan manfaat pula. Pengurus tabungan memanfaatkan dana anggota dengan cara meminjamkan kepada anggota yang memerlukan pinjam. Bonus yang diberikan kepada pengurus dan anggota adalah berdasarkan kesepakatan bersama karna pada prinsipnya akad pada tabungan ini penekannnanya adalah titipan. Tabungan masyarakat ini pula dapat diambil setiap saat atau kapan saja ketika anggota mebuthkan dananya.

Jika dikaitkan dengan teori pada bab II, tabungan masyarakat di kampung Ongan Jaya sesuai dengan akad al-Wadi'ah yad Dhamanah yaitu anggota menitipakan uangnya kepada pengurus tabungan dan pengurus tabungan juga memanfaatkan dana anggota tersebut dengan cara di pinjamkan kepada anggota yang membutuhkan dengan syarat tertentu. Kemudian anggota juga diberi kebebasan oleh pengurus untuk mengambil uangnya kapan saja atau pada saat ada kebutuhan yang mendesak.

Sebagai mana dijelaskan dalam Al-Quran surat an-Nisa ayat 58 dan al- Baqarah ayat 283, dapat disimpulkan bahwa al-Wadi'ah yad Dhamanah adalah suatu titipan uang, dimana pihak yang dititipi boleh memanfaatkan uang tersebut. Namun jika uang tersebut rusak atau hilang maka pihak yang dititipi harus bertanggung jawab atau menggantinya. Dalam dal ini pihak yang dititipi adalah pengurus tabungan. Para pengurus yang telah dititipi sudah semestinya menjaga uang tersebut dengan baik, dan jika terjadi kehilangan maka para pengurus sudah semestinya pula 
bertanggung jawab untuk mengantinya. Pengurus tabungan memanfaatkan uang anggota dengan cara di pinjamkan kepada anggota yang membutuhkan namun, jika anggota tersebut ingin mengambil tabunganya maka diperbolehkan kapan saja.

Hasil dari penelitian ini menunjukkan bahwa tabungan masyarakat yang ada di RT 004 RW 002 kampung Ongan Jaya Distrikk Yapsi Kabupaten Jayapura sudah sesuai dengan hukum Islam dan prinsipprinsip muamalah. Prinsip-prinsip muamalah tersebut antara lain; yaitu hukum asal segala bentuk muamalah dilakukan atas dasar menarik manfaat dan menolak mudharat, dan muamalah dilakukan atas dasar menegakkan keadilan, serta tabungan masyarata ini dapat dikatakan baik karena mengandung kemaslahatan. Tabungan masyarakat ini juga sudah sesuai dengan rukun dan syarat al-Wadi'ah, dimana rukun-rukun alWadi'ah yaitu adanya benda yang dititipkan, adanya dua orang yang berakad dan juga adanya ijab dan qabul.

Hasil penelitian ini sejalan dengan penelitian yang telah dilakukan oleh Nurlita Halimah (2017) dengan hasil penelitian yang menunjukkan bahwa proses transaksi menabung sudah sesuai dengan alWadi'ah dalam fikih muamalah. Hal ini didasarkan pada terpenuhinya syarat dan rukun akad dan tidak bertentangan dengan rukun dan syarat wadi'ah. Karena dalam hal ini ada orang yang menitipkan barang yaitu anggota, serta ada orang yang dititipi barang.

Fenomena tentang bertahannya tabungan masyarakat kampung Ongan Jaya adalah budaya gotongroyong yang masih sangat kenal didaerah pedesaan. Rasa kesetiakawanan dan kepercayaan inilah yang membuat tabungan ini bisa betahan dari awal dibentuknya pada tahun 1997 hingga sekarang meskipun belum memiliki badan hukum yang resmi. Selain itu terinspirasi dari nama tabungan ini yaitu "Ngudi Tentrem" yang memiliki arti mencari ketentraman sehingga masyarakat atau anggota tabungan merasakan mendapat ketenraman dari aktifitas tabungan tersebut. Sehingga masyarakat kampung Ongan Jaya khususnya RT 004 RW 002 lebih memilih tabungan Ngudi Tenrem ini dalam aktifitas menabungnya.

Secara garis besar penelitian ini mendukung penelitianpenelitian yang telah dilakukan sebelumnya dengan hasil yang sama yaitu tabungan masyarakat di RT 004 RW 002 di kampung Ongan Jaya Distrik Yapsi Kabupaten Jayapura sudah sesuai dengan akad al-Wadi'ah yad 
Dhamanah berdasarkan rukun dan syarat al-Wadi'ah dimana sudah terdapat uang sebagai barang yang dititipkan, anggota tabungan sebagai orang yang menitipkan barang, pengrus tabungan sebagai orang yang dititipi dan juga shigat atau ijab qabul. Tabungan anggota dapat diambil kapan saja dan juga dapat di manfaatkan oleh pihak yang dititipi untuk mendapatkan keuntungan dengan ketentuan jika uang tersebut rusak atau hilang akan menjadi tanggung jawab pihak yang dititipi.

2. Upaya pengurus dalam menyelesaikan permasalahan kredit macet anggota tabungan di kampung Ongan Jaya.

Sebagaimana dari hasil wawancara yang telah dilakukan oleh peneliti dengan anggota dan pengurus tabungan, ada beberapa sebab yang mempengaruhi timbulnya kredit macet pada tabungan masyarakat kampung Ongan Jaya yaitu:

a. Ketidak jujuran anggota dalam penggunaan kredit untuk produktif menjadi konsumtif yang tidak sesuai dengan tujuan dalam perjanian kredit.

b. Faktor pendapatan debitur yang tidak menentu

c. Kurangnya pengawasan oleh pengurus yang menyebabkan debitur dengan mudah melakukan pelanggaran maupun ingakar janji (wanprestasi).

d. Perubahan keadaan yang terjadi akibat bencana yang dapat menyebabkan terjadinya kerugian besar bagi debitur dalam usahanya.

Jika dikaitkan dengan teori pada bab II, upaya pengurus tabungan dalam menyelesaikan permasalahan kredit macet yaitu dengan melakukan peyelamatan kredit dengan cara melakukan rescheduling (penjadwalan kembali). Pengurus melakukan perpanjangan waktu dengan system jika anggota tidak dapat menyelesaikan angguran pinjamannya dalam waktu jatuh tempo 4 bulan, maka sisa angguran yang belum dilunasi oleh anggota tersebuta akan dihitung sebagai pinjaman baru dan juga akan dipotong jasa pinjam yang baru pula. Hal ini diharapkan agar kreditur dapat memiliki waktu tambahan untuk menyelesaikan sisa pinjamanya pada tabungan masyarakat tersebut. Selain itu pengurus juga melakukan restructuring (penataan kembali) terhadap kegiatan perkreditan debitur yang dapat membatu menyelamatkan kesulitan untuk memenuhi kewajibannya dengan cara memberikan penurunan suku bunga 
atau bahkan denagn meniadakan bunga pinjaman kepada anggota yang memiliki permasalahan kredit macet dengan tingkat akut.

Kemudian teori pada bab II juga menyebutkan terdapat cara yang dapat diguankan untuk penyelesaian kredit bermasalah yaitu:

a) Penyelesaian Kredit Bermasalah Secara Damai

Penyelesaian kredit bermasalah secara damai dapat dilakukan terhadap debitur yang beritikad baik untuk menyelesaikan kewajibannya dan cara yang ditempuh dalam penyelesaian ini di anggap lebih baik dibandingkan alternative penyelesaian melalui saluran hukum.

b) Penyelesaian Kredit Bermasalah Melalui Saluran Hukum

Penyelesaian jenis ini dilakukan apabila upaya restrukturisasi/penyelesaian secara damai sudah diuapayakan secara maksimal dan belum memberikan hasil atau debitur tidak menunjukkan itikad baik dalam menyelesaikan kewajibannya, maka penyelesaian dapat ditempuh melalui saluran hukum.

Pengurus tabungan masyarakat di kampung Ongan Jaya dalam menyelesaian masalah kredit macet adalah dengan menggunakan penyelesaian kredit macet secara damai. Penyelesaian jenis ini dianggap lebih baik dibandingkan alternative penyelesaian melalui saluran hukum. Dimana dalam hal ini pengurus tabungan akan memberikan fasilitas keringanan bunga dan juga penghapusan bunga kepada para penunggak dengan kolektibilitas diragukan dan juga macet kredit yang telah dihapus bukukan. Selain itu pengurus juga akan lebih teliti dalam memberikan pinjaman. Dalam hal ini pengurus akan melakukan pengecekan terhadap calon peminjam tentang riwayat peminjaman dan juga kondisi usaha si calon peminjam. Langkah ini diharapkan dapat memperkecil terjadinya resiko kredit macet pada tabungan masyarakat tersebut. Hal ini sudah sejalan dengan upaya penanganan kredit bermasalah yang dilakukan oleh bank syariah.

Hasil penelitian ini menunjukkan bahwa upaya yang dilakukan pengurus tabungan untuk menyelesaikan kredit macet sudah sesuai dengan langkah yang di ambil oleh suatau bank. Dimana pihak bank akan melakukan peyelamatan kredit dengan cara yaitu: Melakukan penjadwalan kembali (rescheduling), melakukan persyaratan kembali (reconditionting), serta melakukan penataan kembali (restructuring) yang bertujuan membantu kreditur untuk memenuhi kewajibanya. Serta penyelesaikan 
kredit macet pun sudah sesuai dengan yang dilakukan oleh bank syariah yaitu melakukan pengecekan terlebih dahulu kondisi pihak penghutang sebelum memberikan pinjaman. Dan juga cara bank untuk menyelesaikan kredit macet secara damai karena dianggap cara ini adalah cara yang lebih baik dibadingakan penyelesian melalui saluran hukum.

Hasil penelitian ini sejalan dengan penelitian yang telah dilakukan oleh I Nyoman Suarjana (2015) dengan hasil penelitian menunjukkan 1) Penyebab terjadinya kredit macet pada koperasi Pasar Srinadi Klungkung tahun 2013 adalah factor internal dan eksternal. Faktor internal yaitu kurang selektifnya pihak koperasi dalam analisis pemberian kredit, itikad tidak baik daripetugas koperasi Pasar Srinadi Klungkung, dan lemahnya system pengawasan kredit. Faktor eksternal yaitu: penurunan kondisi perekonomian, tikad tidak baik dari debitur, dan akibat adanya bencana alam. 2) Dampak kredit bagi koperasi pasar Srinadi Klungkung tahun 2013 yaitu mengurangi pendapatan koperasi, arus kas menjadi tersendat, modal koperasi berkurang dan kepercayaan nasabah berkurang. 3) Upaya yang dilakkukan untukmnegatasi kredit macet pada koperasi pasar Srinadi Klungkung yaitu rescheduling (penjadwalan kembali, restructuring (persyaratan kembali), penyitaan jaminan dan penghapusan kredit.

Fenomena tentang ketiadaan agunan pada tabungan ini adalah selaian karena masih mempertahankan budaya gotongroyong yang masih sangat kenal didaerah pedesaan. Rasa kesetiakawanan dan kepercayaan inilah yang membuat pengurus merasa telah mempercayakan anggota dan tidak menggunakan agunan pada transaksi peminjaman. Pengurus hanya mensyaratkan anggota harus memiliki tabungan agar dapat melakukan pinjam pada tabungan masyrakat di kampung Ongan Jaya tesebut. Serta karena factor belum adanya badan hukum resmi yang dimiliki oleh tabungan.

Secara garis besar penelitian ini mendukung penelitianpenelitian yang telah dilakukan sebelumnya yaitu upaya penyelamatan dan penyelesaian kredit macet yang ada pada tabungan ini sudah sesuai dengan langkah-langkah penyelamatan dan penyelesain kredit macet yang dilakukan oleh sebuah bank. Dimana pengurus telah melakukan restrukturisasi yaitu dengan memberikan perpanjangan waktu kredit dan juga menurunkan suku bunga dan bahkan akan meniadakan bunga pinjaman jika tingkat kolektibilitas sangat diragukan. Dan juga akan 
melakukan pengecekan terbih dahulu kondisi pihak penghutang sebelum memberikan pinjaman. Hal ini dilakukan untuk meminimalisir terjadinya kredit macet.

\section{KESIMPULAN DAN SARAN}

\section{a. Kesimpulan}

Berdasarkan pembahasan di atas, maka dapat disimpulkan:

1. Tabungan masyarakat di RT 004 RW 002 kampung Ongan Jaya Distrik Yapsi Kabupaten Jayapura dalam praktiknya sudah sesuai dengan prinsip akad al-Wadi'ah yad dhamanah, berdasarkan rukun dan syarat al-Wadi'ah dimana sudah terdapat uang sebagai barang yang dititipkan, anggota tabungan sebagai orang yang menitipkan barang, pengurus tabungan sebagai orang yang dititipi dan juga shighat atau ijab qabul. Tabungan anggota dapat diambil kapan saja dan juga dapat di manfaatkan oleh pihak yang dititipi untuk mendapatkan keuntungan dengan ketentuan jika uang tersebut rusak atau hilang akan menjadi tanggung jawab pihak yang dititipi. Fenomena tentang bertahannya tabungan masyarakat kampung Ongan Jaya adalah budaya gotongroyong yang masih sangat kenal didaerah pedesaan. Rasa kesetiakawanan dan kepercayaan inilah yang membuat tabungan ini bisa betahan dari awal dibentuknya pada tahun 1997 hingga sekarang meskipun belum memiliki badan hukum yang resmi.

2. Upaya penyelamatan dan penyelesaian kredit macet yang ada pada tabungan masyarakat RT 004 RW 002 kampung Ongan Jaya ini sudah sesuai dengan langkah-langkah penyelamatan dan penyelesain kredit macet yang dilakukan oleh sebuah bank, dimana pengurus telah melakukan restrukturisasi Fenomena tentang ketiadaan agunan pada tabungan ini adalah selaian karena masih mempertahankan budaya gotongroyong yang masih sangat kenal didaerah pedesaan. Rasa kesetiakawanan dan kepercayaan inilah yang membuat pengurus merasa telah mempercayakan anggota dan tidak menggunakan agunan pada transaksi peminjaman.

\section{b. Saran}

Setelah melakukan penelitian tentang praktik masyarakat kampung Ongan Jaya, maka saran dari penulis diberikan kepada masyarakat dan pihak pengurus tabungan masyarakat diantaranya sebagai berikut : 
1. Dalam mengikuti sebuah kegiatan tabungan masyarakat hendaknya bertanya dahulu kepada pengurus tentang aturan-aturan yang ada di dalamnya sehingga tidak akan terjadi hal-hal yang mungkin tidak di inginkan di kemudian hari yang dilarang dalam bermuamalah.

2. Kepada pihak pengurus tabungan, dalam menghimpun dan mengumpulkan dana sebaiknya memerhatikan aturan yang ada yang mana merujuk dari bersumber hukum Islam. Serta para pengurus sebaiknya segera mengurus badan hukum simpan pinjam dan juga badan pengawas sehingga jika terjadi sesuatu di kemudian hari pengurus tidak kesulitan untuk proses penyelesaiannya.

\section{DAFTAR REFERENSI}

Ahmad Ifham, Ahmad. (2015). Ini Lho Bank Syariah: Memahami bank syariah dengan mudah. Jakarta: PT Gramedia Pustaka Utama.

Andrianto. (2020). Manajemen Kredit Teori dan Konsep bagi Bank Umum. Pasuruan: CV Penerbit Qiara Media.

Anggoto, Albi dkk. (2018). Metodologi Penelitian Kualitatif. Sukabumi: CV Jejak

Ebta Setiawan, (2012), KBBI Online: Pengertian Praktik, (Online), (http://kbbi.web.id, diakses 28 Februari 2020).

Eko Riwayati, (15 Maret 2020) wawancara pribadi

Hadi, Muhmmad. (2019). Paradiqma Masterpiece Keuangan Islam dan Aplikasi di Perbankan Syariah.Yogyakarta:CV Budi Utama.

Hadinoto, Soetanto. (2008). Bank Strategy on Funding and Liability Management Jakarta: PT Gramedia.

Harun. (2017). Fiqh Muamalah.Surakarta: Muhammad University Press.

http://INSuarjana,WCipta,AZukri-Jurnal Pendidikan 2015-ejournal.undiksha.ac.id.

http://N Halimah-2017-repository-iainpurwokerto.ac.id.

Ismail. (2011). Perbankan Syariah. Jakarta: Kencana.

Kuswarno, Engkus. (2009). Metodologi Penelitian Komunikasi Fenomenologi:

Konsepsi, Pedoman, dan Contoh penelitiannya. Bandung: Widya Padjadjaran.

Muryadi. (12 April 2020) wawancara pribadi.

Paulin Kay, Vera. (2013). Tabungan dan Variabel Ekonomi Makro yang Mempengaruhi di Kota Ambon, Politeknik Negeri Ambon No. 1. 
Pujiati, (15 Maret 2020) wawancara pribadi.

Sa'diyah, Muhdayatus, (2019). Fiqih Muamalah II Teori dan Praktik. Jepara: UNISNU PRESS.

Setyawan, Rene. (1994). Pengimpunan Dana. Medan: Universitas Sumatra Utara. Soemitra, Andri. (2016). Bank \& Lembaga Keuangan Syariah Medan: KENCANA. Sri Mulyani, (15 Maret 2020) wawancara pribadi.

Sugyiono. (2014). Memahami Penelitian Kualitatif. Bandung: Alfabet.

Sujana. (2005). Strategi pembelajaran. Bandung: Falah Production.

Sutini, (15 Maret 2020) wawancara pribadi.

Usman, Racmadi. (2003). Aspek-Aspek Hukum Perbankan di Indonesia. Jakarta: PT. Gramedia Pustaka Utama.

Wardi Muslich, Ahmad. (2010). Fiqh Muamalah. Jakarta: Sinar Grafika Offset.

Widayanti, Nuning. (2015). 3 Tabungan Cerdas Anak. Jakarta: Trans Media Perkasa. 